\title{
Water Reservoirs as an Element of Shaping Water Resources of Post-Mining Areas
}

\author{
Piotr Stachowski ${ }^{1 *}$, Karolina Kraczkowska', Daniel Liberacki', \\ Anna Oliskiewicz-Krzywicka' \\ 1 Poznań University of Life Sciences, Institute of Land Improvement, Environment Development and Geodesy, \\ Piątkowska 94, 60-649 Poznań, Poland \\ *Corresponding author's e-mail: pstach@up.poznan.pl
}

\begin{abstract}
The aim of the study was to present the concepts of water reclamation and development of post-mining areas of the Adamów Lignite Mine following the termination of its excavating operation. The reclamation procedures will accelerate the process of restoring the devastated post-mining area to the natural environment and, above all, will contribute to the increase in local water resources. Several water reservoirs with different surface areas and capacities within the final excavations of opencasts were created. The reservoirs are used for water retention, recreation, melioration and flood control purposes, as well as for depositing overburden from other opencast excavations. In total, the construction of 5 water reservoirs will include 4 weirs, 7 monks and 3 culverts with damming as well as a number of kilometres of inflow and outflow channels. The schedule of works and expenditures of the investment amounts to PLN 14,509,512 and is divided into 5 stages, not only covering the construction of the reservoirs, but also the water and drainage infrastructure necessary for their proper operation. All constructed and planned water reservoirs (Przykona, Janiszew, Koźmin, Głowy, Adamów, Koźmin Końcowy and Władysławów) will become new permanent elements of the landscape and the hydrographic network, coupled with the catchment system of the Warta River. They will allow for an increase in the retention capacity of the Adamów Lignite Mine area from the previous 32.3 million $\mathrm{m}^{3}$ to 219.6 million $\mathrm{m}^{3}$ in the perspective of 2023 . They will improve the microclimate of postmining areas and have a positive impact on the lands created as a result of reclamation. They will provide retention for the irrigation of adjacent agricultural areas and help reduce the economic and natural losses caused by flooding. They will open recreational opportunities for the residents of the surrounding areas, characterized by water shortages. The post-mining reservoirs, formed during mining operations, fit perfectly into the Small Retention Program. The existing and planned water bodies are the best proof confirming that the decisions taken in the field of reclamation for water purposes were right. As practice shows, the landscape shaping during the exploitation of lignite is a great opportunity for the post-mining region to create reservoirs in the places where they do not occur in nature.
\end{abstract}

Keywords: water reclamation, landscape shaping, post-mining reservoirs, water management

\section{INTRODUCTION}

Opencast lignite mining is characterised by the exclusion of relatively large areas from the agricultural and forestry use while designating them for mining activities [Bender and Gilewska 2004]. This applies to more than 5 thousand active mines operating in the area of over 26,000 ha, which collectively excavate almost 300 million tonnes of various minerals and ores and produce over 250 million $\mathrm{m}^{3}$ of overburden per year. As the numbers demonstrate, it is a significant contribution. According to the forecasts for the opencast mining industry, the share will continue to increase. However, adverse changes caused by mining activities can be compensated by the reclamation of post-mining areas. In many cases, this process marks the beginning of a new, often more attractive way of land development. The scope and scale of reclamation works correspond to the position of the opencast mining industry in the Polish economy. 
As a result of the reclamation activity, many earth formations are created i.e.: external and internal dumping sites, often elevated above the surrounding area, and different forms with large surfaces for instance final excavations, adapted as water reservoirs [Michalski 2004, Różkowski et al. 2010]. The anthropogenic changes in the environment manifest in landscape transformations, transitions in water relations and depletion of groundwater resources [Stachowski et al. 2013, Mocek-Płóciniak 2014]. Large-scale reclamation of post-mining areas in opencast mines is aimed at the technical preparation of the surface through levelling, constructing the network of roads and drainage ditches, and subsequently, developing and fully restoring their functional properties [Gach et al. 1992, Bender and Gilewska 2004].

Due to the physical characteristics of overburden, the agricultural and forest reclamation used to be a dominant reclamation type introduced in the post-mining areas of the Konin-Turek region. However, opencast lignite mining is a factor that particularly transforms water relations. The hydrographic network, i.e. watercourses, undergoes significant changes, because it incorporates new ditches that take water from the mine drainage system. Small reservoirs that filter the mine water from mineral and organic (coal) slurry are built, and after the completion of mining activity, large water reservoirs are constructed in final excavations of opencasts. Therefore, new concepts and solutions for the development of post-mining areas have emerged. Agreed upon with local governments and developed in detail by the municipal authorities, they show the recreational and sports-oriented tendency in the reclamation of the post-mining areas with the use of water reservoirs constructed in final excavations [Michalski 2004]. The reclamation for water purposes brings multifaceted benefits. The anthropogenic post-mining water reservoirs, along with the management of their surroundings, not only allow for restoring, but also for increasing the landscape and nature values, improve the microclimatic conditions as well as rebuild damaged local ecosystems or shape new (secondary) post-mining landscapes [Fagiewicz and Szulc 2014, Gilewska and Otremba 2015, Pietrzyk - Sokulska 2010]. Constructing a water body increases the level of local water retention and soil moisture, as well as favourably changes the microclimate of adjacent areas. By reconciling the natural and recreational requirements, the aim is to construct a multifunctional water reservoir that strengthens or even initiates tourist traffic, leading to the economic revival of the region. This direction of reclamation works is currently the most desirable among the local government units and meets the growing social expectations. The water reservoir built in the final working fits perfectly into the small retention programme, which is extremely important for southeast Wielkopolska (Greater Poland Province) [Stachowski et al. 2010].

So far, the Polish lignite mining industry has conducted water reclamation and management of post-mining excavations on a small scale. The first post-mining water reservoir was created from the Morzysław opencast of the Konin Lignite Mine. In 1961, the Niesłusz opencast ceased its operation and the excavation void was to be transformed into a water body. In 1971, the Gosławice opencast completed its mining, and the subsequently constructed reservoir, with an area of 320 ha and the maximum depth of $27 \mathrm{~m}$, was the largest post-mining lake in Poland for a long time. Since 2003, the Kazimierz Poludnie opencast has been filled with surface water taken from the Struga Biskupia river; ultimately, the reservoir will store 2 million $\mathrm{m}^{3}$ of water.

The aim of the study is to present the concepts of water reclamation and development of post-mining areas of the Adamów Lignite Mine following the termination of its excavating operation. These procedures will accelerate the process of restoring the devastated post-mining terrain to the natural environment and contribute to increase the local water resources. The brown coal deposits excavated in the Adamów Lignite Mine are located in Turek Glacial Upland, and are part of the South Greater Poland Lowland macro-region. The region is characterised by the lack of water bodies and bigger watercourses, low annual precipitation, uneven rainfall distribution and general water deficit. Additionally, mining activities have caused major changes in the hydrological network, not only by liquidating, transitioning or reconstructing the existing riverbeds, but also by creating new water storage facilities. These include "dirty" water settlers and retention reservoirs created in the excavation voids as part of water reclamation. 


\section{WATER RESERVOIRS CREATED IN THE POST-MINING AREAS OF THE ADAMÓW LIGNITE MINE}

As a result of the mining operations, consisting in removing the overburden, placing it in external dumping sites and excavating lignite for the needs of the power plant, the final stage of dumping is typified by significant soil shortages in final excavations (Fig. 1). In the Adamów Lignite Mine, several water reservoirs with different surface areas and capacities were created in its final excavations of opencasts. The reservoirs are used for retention, recreation, melioration and flood control purposes, as well as for depositing the overburden from other opencast excavations (Fig.2). Since the beginning of the Adamów Lignite Mine operation, the area of land reclaimed for water purposes have amounted to 514 ha, including 424 ha of land transferred and sold after reclamation.

This applies to four mining excavations, the areas of which have been transferred for water reclamation (Bogdałów, Władysławów, Janiszew and Przykona). These reservoirs built during the mining activities were created in the process of shallowing excavations. The basins were made of dump soils i.e.: clay, loam, silt, sand and gravel.

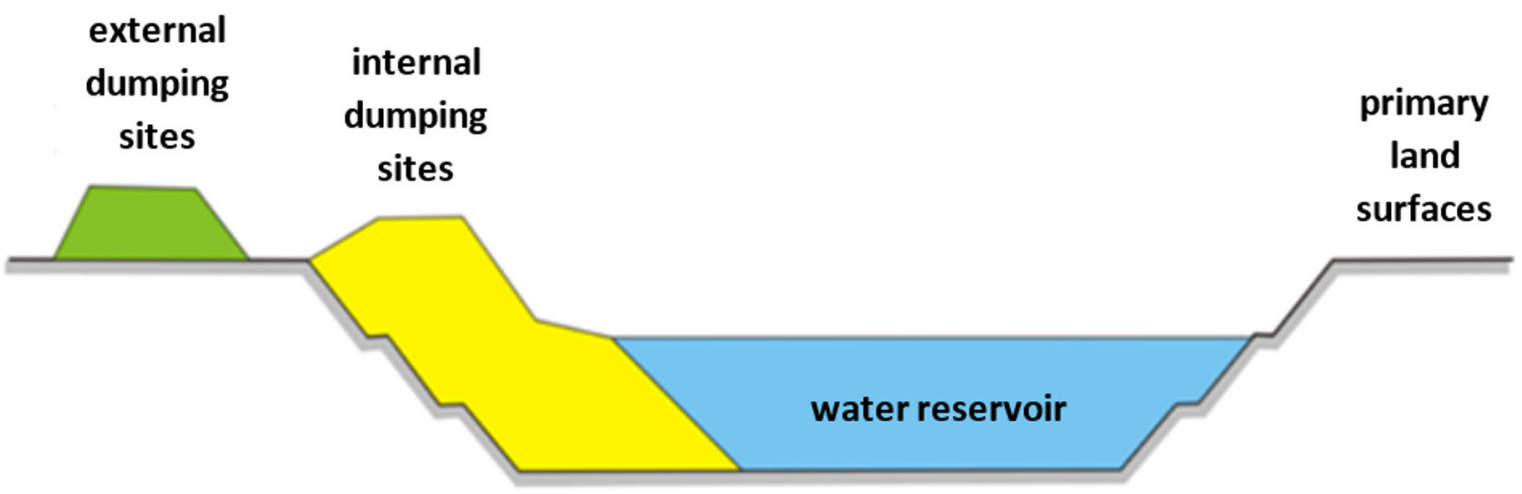

Fig. 1. Diagram of the reservoir in the post-mining excavation [Polak, Chodak, Sypniowski, 2011]

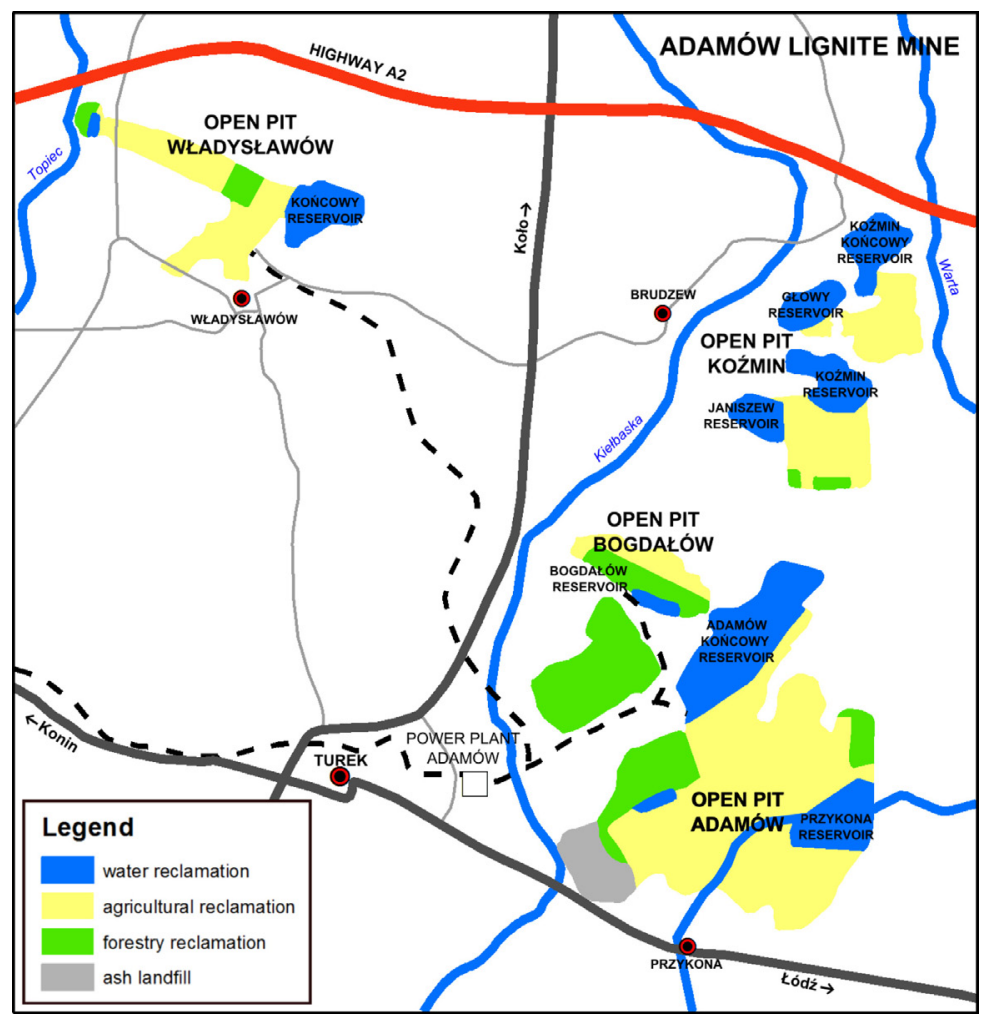

Fig. 2. Directions of post-mining land reclamation in the "Adamów” Lignite Mine [Kasztelewicz, 2010] 
The reservoirs are several meters deep and have gently shaped scarps for ensuring greater stability, possibility of introducing water vegetation or an accessible beach. The reservoirs were filled with water in different periods of time, dependent on the water inflow. Spontaneous filling may last from a few to several years. In order to shorten the required time, the filling process was carried out by the use of clean mine water taken from the drainage system of other opencasts. The Mine handed the reservoirs over to local governments, which proceeded with further development by use of their own means, accounting for the specific natural features of surrounding areas.

The first water reservoir of this type was constructed between 1997-2000 within the internal dumping site of Adamów opencast in the Przykona commune [Orlikowski and Szwed $2009,2011]$. It is located in the original riverbed of the Teleszyna Środkowa river, which formerly ran through the mine area; however, it was liquidated as a result of the conducted mining operations. The reservoir with the basin area of 168.59 ha at the level of the upper edge of escarpment and the maximum flooding area of 139.73 ha has a capacity of 5.915 million $\mathrm{m}^{3}$. The maximum depth of the reservoir is $5.5 \mathrm{~m}$. It features an island with the area of 3.43 ha (Fig.3). In 2001, the reservoir was supplied with mine water from the Adamów opencast's subsoil drainage system, owing to which it was possible to shorten the filling time from 10 to 2 years. The reservoir is supplied with the water from the Teleszyna river (including the Teleszyna-Kiełbaska channel) and from its own catchment area. Its flow-through nature allows for a periodic water exchange and supply from the Teleszyna Dolna river.

The Janiszew reservoir was another reservoir created during mining operations by means of a special technological system (excavator, belt conveyor, stacker and bulldozer). The reservoir was built in 2007 within the internal dumping site of Koźmin opencast in the Brudzew commune. The maximum reservoir depth is $10.0 \mathrm{~m}$. In February 2008, the reservoir was supplied with the mine water taken from the drainage system of Adamów opencast with the use of a purpose-built inflow channel. After filling the reservoir, the excess water will flow through the outflow channel to the Struga Janiszewska river. The water from the drainage system of Adamów opencast will supply the reservoir until the end of excavation operations in the mine, which is predicted to be around 2020.
The post-mining landscape of Adamów Lignite Mine is also characterised by settling reservoirs, where the mine water with mineral and organic (coal) suspension is filtrated in the process of gravity sedimentation. These include:

- The Adamów settling reservoir with an area of 7.9 ha, located within the internal dumping site of Adamów opencast in the Przykona commune.

- It was put into operation in 1985. It is designed for the water inflow of $\mathrm{Q}_{\mathrm{av}}=20.0 \mathrm{~m}^{3} / \mathrm{min}$ and $\mathrm{Q}_{\max }=40.0 \mathrm{~m}^{3} / \mathrm{min}$, and provides min. 24hour water retention time. The water from the reservoir is taken through a mining ditch to the Struga Janiszewska channel, and further to the Kiełbaska river.

- The Koźmin settling reservoir with an area of 16.2 ha, located within the Brudzew commune. It was constructed between the years 1978-79; initially, the treated water from the surface drainage system of the Bogdałów Lignite Mine. At first, it took the water from the Koźmin opencast and the treated water from its surface drainage system. It is designed for the water inflow of $\mathrm{Q}_{\mathrm{av}}=30 \mathrm{~m}^{3} / \mathrm{min}$ and $\mathrm{Q}_{\max }=40 \mathrm{~m}^{3} / \mathrm{min}$, and provides min. 24-hour water retention time. The water from the reservoir is taken to the Kiełbaska river.

- The Janiszew settling reservoir with an area of 5.38 ha, water table area of 5.06 ha and total volume of $150000 \mathrm{~m}^{3}$. The reservoir is designed for the water inflow of $\mathrm{Q}_{\mathrm{av}}=32.5 \mathrm{~m}^{3} / \mathrm{min}$

Table 1. List of water reservoirs that will remain after liquidation of the Adamów Lignite Mine

\begin{tabular}{|l|c|c|c|}
\hline Water facility & $\begin{array}{c}\text { Creation } \\
\text { date }\end{array}$ & $\begin{array}{c}\text { Water table } \\
\text { area (ha) }\end{array}$ & $\begin{array}{c}\text { Volume } \\
\text { (million } \mathrm{m}^{3} \text { ) }\end{array}$ \\
\hline $\begin{array}{l}\text { Bogdałów } \\
\text { reservoir }\end{array}$ & 1994 & 10.8 & 0.60 \\
\hline $\begin{array}{l}\text { Przykona } \\
\text { reservoir }\end{array}$ & 2001 & 139.7 & 7.30 \\
\hline $\begin{array}{l}\text { Janiszew } \\
\text { reservoir }\end{array}$ & 2007 & 59.6 & 4.05 \\
\hline $\begin{array}{l}\text { Koźmin } \\
\text { reservoir }\end{array}$ & 2012 & 108.5 & 6.10 \\
\hline $\begin{array}{l}\text { Głowy } \\
\text { reservoir }\end{array}$ & 2013 & 63.5 & 17.70 \\
\hline $\begin{array}{l}\text { Koźmin } \\
\text { Końcowy }\end{array}$ & 2020 & 116.1 & 34.1 \\
\hline $\begin{array}{l}\text { Władysławów } \\
\text { reservoir }\end{array}$ & 2015 & 103.0 & 20.40 \\
\hline $\begin{array}{l}\text { Adamów } \\
\text { Końcowy }\end{array}$ & 2023 & 462.0 & 161.70 \\
\hline
\end{tabular}

*The surface area is determined according to the master map at scale of 1:10,000 and the volume on the basis of the average reservoir depth. 


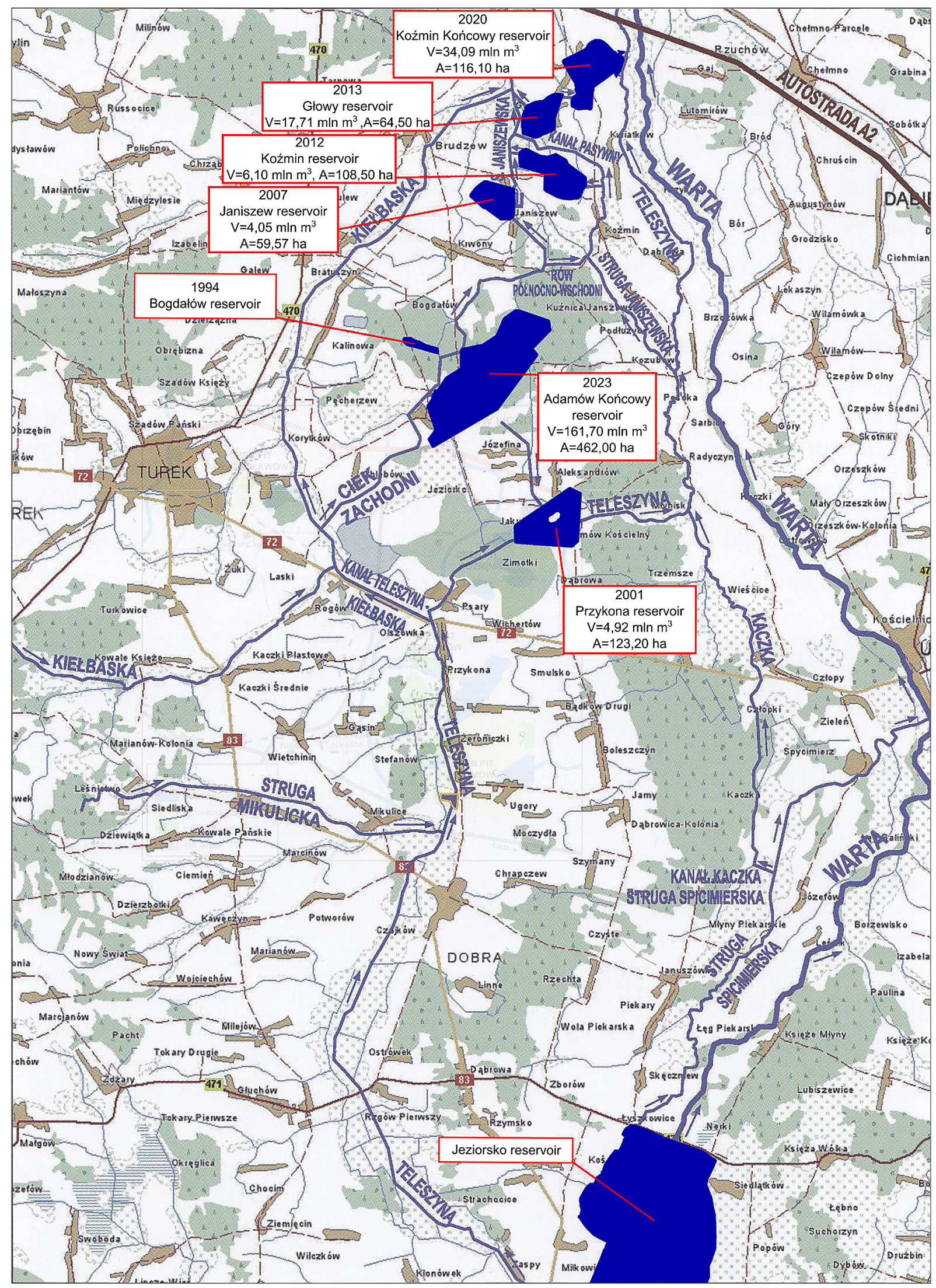

Fig. 3. New hydrographic system within the area of the Adamów Lignite Mine in Turek 
and $\mathrm{Q}_{\max }=47.0 \mathrm{~m}^{3} / \mathrm{min}$, providing a 36-hour water retention time. The water from the reservoir will be taken through a mining ditch to the Struga Janiszewska river.

- The Władysławów settling reservoir with an area of 5.4 ha, located within the internal dumping site of Władysławów opencast. It was put into operation in 1980. It is designed for the water inflow of $\mathrm{Q}_{\mathrm{av}}=0.4 \mathrm{~m}^{3} / \mathrm{s}$ and $\mathrm{Q}_{\max }=0.6 \mathrm{~m}^{3} / \mathrm{s}$, providing a 24-hour water retention time. The water from the reservoir is taken to the Topiec river.

It is particularly worth noting that the settling reservoirs were not liquidated after the completion of lignite exploitation and the gradual liquidation of the Adamów Lignite Mine. In the future, they will be transformed into ecological use, i.e. ponds. The long-term functioning of settling reservoirs has already turned the surroundings of the post-mining area into a natural ecosystem, which has become a decorative landscape element. The Bogdałów reservoir that was created in the final working of Bogdałów opencast is a special example of this type of facility. It is a small water body (with an area of 10.8 ha and depth of $10 \mathrm{~m}$ ) designed to store water for the fire-fighting purposes. Its small dimensions result from the fact that the remaining part of excavation void was filled with the overburden from the Koźmin opencast, transported from the opening cut of the Koźmin opencast to the Bogdałów opencast over a distance of approx. $7 \mathrm{~km}$. Thus, circa 164 ha of the area that would otherwise be used as an external dumping site elevated above the surrounding terrain was saved.

\section{WATER RESERVOIRS PLANNED IN THE POST-MINING AREAS OF THE ADAMÓW LIGNITE MINE}

Additional reservoirs are planned or under construction within the area of internal dumping in the Koźmin opencast: Koźmin reservoir, Głowy reservoir, Koźmin Końcowy reservoir (around 2020) and Adamów reservoir. These reservoirs are to be created between 2009 -2023 and will occupy a total of 750.1 ha with the capacity of approx. 220 million $\mathrm{m}^{3}$ (Tab.1). By 2023, the reservoirs will have increased the retention level of the Adamów Lignite Mine area from the previous 32.3 million $\mathrm{m}^{3}$ to 225.7 million $\mathrm{m}^{3}$.
Interestingly, it is anticipated that the water in the reservoirs will be able to back up by $0.20 \mathrm{~m}$ to obtain a constant flood reserve in the total of 1.502 million $\mathrm{m}^{3}$. This is all the more important, since the total estimated loss on evaporation is calculated to be approx. 2.03 million $\mathrm{m}^{3}$. The post-mining reservoirs will be made of dump soils in the process of shallowing mine workings. The reservoirs will be shallow, a few to several meters deep. Scarps will be appropriately contoured to ensure their stability with the inclination of $1: 4 \div 1: 5$; however, the separated fragments designated for recreation will incline $1: 10 \div 1: 15$.

Regardless of these shallow water reservoirs, the final mining excavations of each opencast will be changed into a final reservoir. After the completion of the lignite exploitation from the Koźmin deposit (around 2020), the Koźmin Końcowy reservoir will be created in its final excavation. The scarps of the working will form the reservoir ba$\sin$, and its footwall - the reservoir bottom. With the capacity of 34.1 million $\mathrm{m}^{3}$, it will be the largest (116.1 ha) and the deepest $(42 \mathrm{~m})$ reservoir in the area of the Koźmin opencast. At the water level of $93.30 \div 93.80 \mathrm{~m}$ a.s.1., located $0.2 \div 2.2 \mathrm{~m}$ below the ground level, it will be possible to impound water in the reservoir by $0.2 \mathrm{~m}$ in order to obtain a constant flood reserve of 0.232 million $\mathrm{m}^{3}$. From 2023, the reservoir will be filled with the groundwater from the drainage wells in the reservoir bowl. After around 2 years of filling, the reservoir will be supplied with the water from the Jeziorsko reservoir. This will allow for connecting it with the Warta river water system, but above all, it will compensate the losses due to the water infiltration to the depression cone, which is estimated to be approx. 0.313 million $\mathrm{m}^{3}$.

After completion of the lignite exploitation from the Adamów deposit (around 2023), a water reservoir will be created in its final excavation. The Adamów Końcowy reservoir with the basin area of 502.5 ha at the level of the upper edge of escarpment, and the maximum flooding area of 462 ha will have a capacity of 161,7 million $\mathrm{m}^{3}$. Similarly as the Koźmin Końcowy reservoir, in the first stage it will be filled with the groundwater from the drainage wells in the reservoir basin. The estimated filling time is 15 years (from 2024). The reservoir will be supplied with the groundwater naturally flowing from the rock mass to the reservoir basin and the water from the Warta River catchment area, upon the exclusion of the subsoil drainage system. It is anticipated that the reservoir will be filled within 10 to 12 years. 


\section{WATER MANAGEMENT USING THE POST- MINING RESERVOIRS}

The reservoirs will be supplied with the water from the mine drainage system, which allows for a significant reduction in filling time. Furthermore, the system will use disposable water resources from the catchment areas of reservoirs and watercourses as well as from the Jeziorsko reservoir. The Janiszew reservoir will be supplied with the water from the catchment of northeast ditch and its own. The Koźmin reservoir, the Głowy reservoir and the Koźmin Końcowy reservoir will be supplied with the water from its own catchment areas, the Struga Janiszewska catchment area, the Passive Channel and the water from the catchment area of the Teleszyna Dolna river. The distribution of water for supplying the reservoirs will be controlled at the Sarbinka node. The Adamów Końcowy reservoir will be supplied with water from the catchment areas of: the Teleszyna Górna river, the Kiełbaska Duża river, the Teleszyna-Kiełbaska channel and the water pumped through the Miłkowice pumping station from the Jeziorsko reservoir. After filling the reservoir, the water resources from the Kiełbaska Duża river will be sufficient to cover the losses on evaporation and maintain a stable water table. The Przykona reservoir is supplied from its own catchment area, the catchment areas of Teleszyna Środkowa and Teleszyna Górna as well as from the Jeziorsko reservoir through the Miłkowice pumping station. Additionally, the reservoir will be partially supplied with the water from the subsoil drainage system of Adamów opencast. The water management system will use: the weirs and sluices already in operation or planned for construction; on the Teleszyna Dolna river, the Passive Channel, the damming culvert of Ciek Zachodni as well as the Kaczka-Struga Śpicimierska water channel $(\mathrm{km} 12+690)$ of the Kaczka river. Firstly, the weirs on the Struga Janiszewska riverbed located within the mine (the Passive Channel) will be constructed.

The first structure will allow for directing the water through the northeast ditch to the Passive Channel and the Janiszew reservoir, the second facility will apply the same to high water, instead of directing it to the Struga Janiszewska river and to the Kiełbaska river. The Koźmin reservoir: inlet structures; monks and culverts with damming, located on the inlet channels that will enable to supply the reservoirs: damming structures; the monks constructed on the outflow channels from: the Janiszew reservoir, the Koźmin reservoir, the Głowy reservoir and the Koźmin Końcowy reservoir.

In total, the construction of 5 water reservoirs in the Adamów Lignite Mine includes 4 weirs, 7 monks and 3 culverts with damming as well as a number of kilometres of inflow and outflow channels. The schedule of works and expenditures of the investment amounts to PLN 14.509.512 and is divided into 5 stages, not only covering the construction of the reservoirs, but also the water and drainage infrastructure necessary for their proper operation.

The stage I, implemented between 2008-2009 for PLN 2.085.400 (the price level as of 2008), included the following renovation works: the Struga Janiszewska river to the outlet of the Passive Channel, the sluice (Sarbinka node) on the Teleszyna Dolna river, the weir on the Struga Janiszewska river and the weir on the Passive Channel.

The stage II, implemented between 2009-2010, included the renovation works on: the Koźmin reservoir, the weir on the Passive Channel, the inflow channel with a length of $500 \mathrm{~m}$, the monk on the inflow channel, the outflow channel with a length of $400 \mathrm{~m}$ (for PLN 801,000).

The stage III, implemented between 2011-2013, included renovation works on the Kaczka river i.e.: the water channel linking the Struga Śpicimierska river with the Kaczka river with facilities and the Trzemeszka river with facilities. The scope additionally included the renovation works of the sluice on the Teleszyna Dolna, the Głowy reservoir, the weir on the Passive Channel and two monks, for PLN 6.035.112.

The stage IV (to be implemented between 2018-2020) involves the construction of the Koźmin Końcowy reservoir, the weir on the

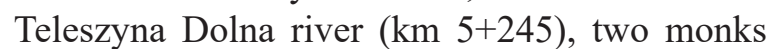
as well as the outflow and inflow channels, for PLN 3.763.000.

The last stage of water infrastructure development $(\mathrm{V})$ with the projected implementation between 2020-2023 is evaluated to absorb the total amount of PLN 1.825.000. The following works are planned: construction of the Adamów reservoir, renovations of the weir on the Kiełbaska Środkowa river $(\mathrm{km} \mathrm{32+160)}$ and renovations of the Rów Zachodni and Ciek Zachodni channels (supplying the reservoir with water). 
In connection with the mining works, the hydrographic network within the area of the Adamów Lignite Mine has undergone a significant transformation. The riverbeds were relocated beyond the lignite mining area and adapted to receive the inflow of mine water. New ditches and channels operating within the drainage system of the mine were constructed. All the constructed and planned water reservoirs (Przykona, Janiszew, Koźmin, Głowy, Adamów, Koźmin Końcowy and Władysławów) will become new permanent elements of the landscape and the hydrographic network, coupled with the catchment system of the Warta River (Fig.3). In the area of the Turek administrative district, where there are no lakes with adequate natural and landscape values, the share of water bodies in the total area of the district will increase. They will improve the microclimate of post-mining areas and positively affect the arable and forestry lands created as a result of reclamation. They will provide retention for irrigation of the adjacent agricultural areas and help reduce the economic and natural losses caused by flooding. They will open recreational opportunities for the residents of surrounding areas characterised by water shortages. The post-mining reservoirs, formed during mining operations, perfectly fit into the Small Retention Program, implemented in Poland on the basis of the agreement of December 21, 1995 concluded between the Ministry of Agriculture and Food Economy and the Ministry for Environmental Protection, Natural Resources and Forestry. It assumes, for instance, the construction of artificial water reservoirs with a capacity of up to 5 million $\mathrm{m}^{3}$.

The above-mentioned examples of the existing and planned water reservoirs are the best proof for the rightness of decisions taken in the field of reclamation for water purposes. As practice shows, landscape shaping during the exploitation of lignite, is a great opportunity for the postmining region to create reservoirs in the places where they do not occur in nature. Artificial water reservoirs can help resolve a broadly understood problem of water management; serve for agricultural irrigation and flood protection, provide a recreational base for residents as well as diverse habitats for "newly created" fauna and flora. Reservoirs can collect water coming from drainage systems of opencasts or excavations so it will not be irreversibly lost. In addition, they can provide profitability for the investor. Treating reclamation as an investment might bring benefits to the mine and increase the value of the region in the future.

\section{CONCLUSIONS}

Reservoirs in excavation voids are new, but increasingly common features of the landscape in the post-exploitation areas of the lignite mining industry. Due to the progress of mining works, unfavourable balance of earth masses, as well as an approaching end date of brown coal exploitation in all lignite-mining areas in Poland, postmining excavations will most often be developed into water reservoirs. The water bodies located in the post-mining areas of the Adamów Lignite Mine are a model example of using the plant's technical capabilities in an innovative approach to shape the post-mining landscape. It is also an exemplary model of prime cooperation between the local government and the mining plant in the field of revitalization of the post-mining area. In the post-exploitation area of the Adamów Lignite Mine, the reservoirs created as part of water reclamation of the final workings of opencasts will remain permanent hydrological objects.

Galiniak et al. [2014] recognize the formation of anthropogenic reservoirs in excavation voids as a factor determining the success of the opencast mining industry in the sozological practice. According to Orlikowski and Szwed [2009, 2011], reclamation for water purposes in the Adamów Lignite Mine is a promising investment in the future of the region, since the surface area of open water in the region has significantly increased, which also contributed to more balanced water flow in the region. All the constructed and planned water reservoirs (Przykona, Janiszew, Koźmin, Głowy, Adamów, Koźmin Końcowy and Władysławów) will become new permanent elements of the landscape and the hydrographic network, coupled with the catchment system of the Warta River (Fig.3). In the area of the Turek administrative district, where there are no lakes with adequate natural and landscape values, the share of water bodies in the total area of the district will increase. They will improve the microclimate of the post-mining areas and positively affect the arable and forestry lands created as a result of reclamation. They will provide retention for irrigation of the adjacent agricultural areas and help reduce the economic and natural losses caused by flooding. They will open recreational opportunities for the residents of surrounding areas characterised by water shortages. The post-mining reservoirs, formed during mining operations, perfectly fit into the Small Retention Program that is of major im- 
portance for southeast Wielkopolska (Greater Poland Province). The above-mentioned examples of the existing and planned water reservoirs are the best proof for the rightness of decisions taken in the field of reclamation for water purposes. As practice shows, landscape shaping during the exploitation of lignite, is a great opportunity for the region to create reservoirs in places where they do not occur in nature. Artificial water reservoirs can help resolve a broadly understood problem of water management; serve for agricultural irrigation and flood protection, provide a recreational base for residents as well as diverse habitats for "newly created" fauna and flora. They also can collect the water coming from the drainage systems of opencasts or excavations so it will not be irreversibly lost. The reservoirs have become an attractive place for vegetation growth and habitats for numerous species of animals, especially birds and fish. This process has increased the value of water region and its surrounding area. The area developed by the Adamów Lignite Mine has began to attract tourists and contributed to the development of recreation. There are swimming facilities, sandy beaches and rest areas. The development of post-mining areas for water purposes has become an attractive and expected destination for the reclamation of post-mining areas of the Adamów Lignite Mine. As seen in the case of water reservoirs, it can be concluded that opencast mining does not have to be perceived as the industry branch that devastates the surrounding environment. On the contrary, after water reclamation and creation of new reservoirs, it might positively contribute to a new, embellished landscape. Treating reclamation as an investment might bring benefits to the mine and increase the value of the region in the future.

\section{REFERENCES}

1. Bender J., Gilewska M. 2004. Reclamation in the light of investigations and implementation (in Polish). Roczniki Gleboznawcze. LV, no. 55 (2) Warsaw, 29-46.

2. Gach S., Kasztelewicz Z., Kica J., Michalski A., Świder M., Kowalczykiewicz Z., Adamski J. 1992. Eksploatacja węgla brunatnego, a ochrona środowiska (in Polish). KWB Konin-Kleczew, 5-25.

3. Galiniak G., Polak K., Różkowski K., Kazanowska-Opala K., Pawlecka K. 2014. Water reclamation as a factor determining the success of the opencast mining industry in the sozological practice (in Polish). Przegląd Górniczy, 10, 122-127.

4. Gilewska M., Otremba K. 2015. Functions of hydrological objects in the post-mining areas of "Władysławów" open pit (in Polish). Inżynieria Ekologiczna, 44, 104-108.

5. Fagiewicz K., Szulc M. 2014. Impact of lignite exploitation on the spatial structure and functioning of landscape systems - a case study of the Władysławów opencast (in Polish). Przegląd Górniczy, 7, 140-157.

6. Kasztelewicz Z. 2010. Rekultywacja terenów pogórniczych w polskich kopalniach odkrywkowych (in Polish). Wydawnictwo AGH Kraków.

7. Michalski A. 2004. Development of post-mining areas of the 'Adamów' Lignite Mine in Turek and the 'Konin' Lignite Mine in Kleczewo (in Polish). Roczniki Gleboznawcze, vol. LV, no. 2, 281-291.

8. Mocek-Płóciniak A. 2014. Biological reclamation of areas degraded after excavation of lignite and copper ores (in Polish). Nauka-Przyroda-Technologie, |Department: Rolnictwo, 8(3), 1-9.

9. Orlikowski D., Szwed L. 2009. Water reclamation at the Adamów Lignite Mine - investment in the future of the region (in Polish). Górnictwo i Geoinżynieria, 2, 351-361

10. Orlikowski D., Szwed L. 2011. Development of post-mining areas of the Adamów Lignite Mine in Turek - landscape before mining and after its completion (in Polish). Górnictwo i Geoinżynieria, 3/35, 225-240.

11. Polak K., Chodak M, Sypniowski S., Problemy wodnej rekultywacji wyrobisk kruszyw naturalnych (in Polish). Akademia Górniczo-Hutnicza w Krakowie, Kraków 2011.

12. Pietrzyk-Sokulska E. 2010. Water reservoirs in post-mining quarries - new component of city's landscape attractiveness (in Polish). Landscape and Tourism. Prace Komisji Krajobrazu Kulturowego PTG, Sosnowiec, 14, 264-272.

13. Różkowski K., Polak K. Cała M. 2010. Selected problems related to water reclamation of excavations (in Polish). Górnictwo i Geoinżynieria, 4, 517-525.

14. Stachowski P. 2010. Assessment of Meteorological Droughts on the Postmining Areas in the Konin Region (in Polish). Annual Set The Environment Protection, 12, 587-606.

15. Stachowski P., Oliskiewicz-Krzywicka A., Kozaczyk P. 2013. Ocena warunków meteorologicznych na terenach pogórniczych Konińskiego Zagłębia Węgla Brunatnego (in Polish). Annual Set The Environment Protection, 15, 1834-1861. 